\title{
Risk factors and genetic characterization of bovine respiratory syncytial virus in the inner Aegean Region, Turkey
}

\author{
Ömer Barış İnce ${ }^{1}$ Murat Şevik ${ }^{2} \cdot$ Emrah Gökay Özgür $^{3} \cdot$ Ahmet Sait $^{4}$
}

Received: 4 May 2021 / Accepted: 3 December 2021 / Published online: 9 December 2021

(c) The Author(s), under exclusive licence to Springer Nature B.V. 2021

\begin{abstract}
Bovine respiratory syncytial virus (BRSV) is one of the causative viral agents of the bovine respiratory disease complex. This study was conducted to determine the seropositivity and risk factors associated with BRSV infection and to evaluate the phylogenetic relatedness of the BRSVs in the inner Aegean region of Turkey. In this cross-sectional study, serum samples $(n=557)$ and nasal swabs $(n=21)$ were collected from cattle herds $(n=43)$ between February 2018 and March 2019. A commercial indirect-ELISA kit was used for the detection of antibodies in the sera samples. Reverse-transcriptase PCR was used to detect viral RNA in nasal swabs. Nasal samples were also examined for the detection of bovine parainfluenza-3, bovine viral diarrhoea virus, and bovine herpesvirus 1 by molecular detection methods. Genetic characterization of the local BRSV field isolates was conducted by sequencing attachment glycoprotein $(G)$ gene segment. Epidemiological data on potential risk factors were collected from each sampled herd during blood collection. All herds had at least one seropositive animal. After adjustment for assay sensitivity and specificity, the overall true seropositivity was $58.48 \%$ (95\% CI: 53.32-63.47). BRSV RNA was detected in 2 of the 21 nasal swabs, whereas other infectious agents were not detected in the investigated samples. Phylogenetic analysis showed that the field isolates of BRSV obtained in this study belonged to subgroup III, but they were located on separate branch from previously characterised Turkish subgroup III isolates. BRSV field strains from this study displayed 3 new amino acid substitutions (P89S, D115G, and S165L) in the G protein chains compared to other main reference BRSV isolates, demonstrating that BRSV is still evolving. Generalised estimating equation model showed that there were positive associations between BRSV infection, age $(\mathrm{OR}=2.36, p=0.001)$, herd size $(\mathrm{OR}=10.32, p<0.001)$, herd type $(\mathrm{OR}=8.97, p<0.001)$, a past history of respiratory disease $(\mathrm{OR}=4.06, p<0.001)$. The results of this study revealed that BRSV infection is common among cattle herds in the inner Aegean region of Turkey. The obtained epidemiological and genetic data on BRSV infection from this study could be beneficial for designing effective biosecurity practices and vaccination strategies.
\end{abstract}

Keywords Cattle $\cdot$ Bovine respiratory syncytial virus $\cdot$ Risk factors $\cdot$ Seroprevalence $\cdot$ Genetic characterization $\cdot$ Turkey

Ömer Barıș İnce

incebaris@gmail.com

1 Animal Breeding and Genetic Research and Implementation Center, Pamukkale University, Kinikli Campus, 20100 Pamukkale, Denizli, Turkey

2 Department of Virology, Necmettin Erbakan University, Veterinary Faculty, 42310 Eregli, Konya, Turkey

3 Faculty of Medicine, Department of Biostatistics and Medical Informatics, Kocaeli University, 41380 Kocaeli, Turkey

4 Pendik Veterinary Control Institute, Viral Diagnostic Laboratory, 34890 Pendik, Istanbul, Turkey

\section{Introduction}

Bovine respiratory syncytial virus (BRSV, renamed as bovine orthopneumovirus), a non-segmented negativestrand RNA virus, is a member of the family Pneumoviridae (ICTV, 2019). Its genome has nine structural proteins: the attachment glycoprotein $(\mathrm{G})$, fusion protein $(\mathrm{F})$, RNA polymerase $(\mathrm{L})$, matrix protein $(\mathrm{M})$, nucleoprotein $(\mathrm{N})$, the polymerase cofactors M2-1 and M2-2, phosphoprotein (P), and small hydrophobic protein (SH) (Valarcher and Taylor 2007). The $G$ and $F$ genes are immunogenic antigens, and they have important roles in viral infectivity (Valarcher and Taylor 2007). Genetic analysis of the $G$ and $F$ proteins 
indicates that there are eight subgroups for the BRSV (Krešić et al. 2018).

BRSV infects sheep and goats, but infection usually occurs in cattle (Sarmiento-Silva et al. 2012). BRSV primarily affects young animals (especially 3 to 12 -month-old calves) following the introduction of the virus into a herd. Although adult animals can be clinically or subclinically infected, severe clinical signs are seen mostly in young calves including upper and lower respiratory damage. The main symptoms are fever, coughing, loss of appetite, increased breathing rate, and nasal discharge (Valarcher and Taylor 2007). Furthermore, BRSV infection can increase the risk of secondary bacterial infections that can result in pneumonia (Brodersen 2010). The morbidity rate varies between 60 and $80 \%$, and mortality rate varies between 2 and 3\%, but it may reach up to $20 \%$ in calves (Elvander 1996; Valarcher and Taylor 2007).

Literature on the transmission of BRSV reported that the virus is mainly transmitted via aerosols, fomites, direct contact with infected animals, and humans as passive vectors (Norström et al. 2000; Valarcher and Taylor 2007). Infection is more prevalent in the autumn and winter seasons, and intensification practices, environmental stress factors, herd size, and age distribution can influence the occurrence of disease (Van der Poel et al. 1994; Norström et al. 2000; Sacco et al. 2014; Ferella et al. 2018). Although vaccination and biosecurity are effective methods of preventing BRSV infection, prevalence of infection is higher in developing countries because of the cost of control programs and the absence of information on the risk factors associated with BRSV (Norström et al. 2000; Saa et al. 2012; Ferella et al. 2018).

There is limited knowledge available about the prevalence of BRSV infection (Yavru et al. 2005; Yeşilbağ and Güngö, 2008; Kadiroğlu et al. 2020) and genetic features of BRSV strains circulating in Turkey (Hacığlu et al. 2019; Timurkan et al. 2019; Yazici et al. 2020). Furthermore, the possible risk factors for BRSV infection in cattle have not been studied in Turkey. To establish a successful control program, they are important to determine the infection prevalence and risk factors associated with disease. The aims of this study were therefore to determine the seropositivity and risk factors associated with BRSV infection and to identify genetic variations of the BRSVs circulating in the inner Aegean region of Turkey.

\section{Material and methods}

\section{Study area}

The study was carried out in cattle herds $(n=43)$ in the Afyonkarahisar and Uşak Provinces, located within $37^{\circ} 45^{\prime}$
North and $39^{\circ} 17^{\prime}$ North latitudes and $28^{\circ} 97^{\prime}$ East and $31^{\circ}$ $43^{\prime}$ East longitudes, in the inner Aegean region of Turkey (Fig. 1). The study area is one of the major livestock centres in the Aegean region with approximately 600,000 cattle (TUIK, 2019). According to the Köppen-Trewartha climate classification, the study area has a continental temperate climate (average low-temperature and average high-temperature is $-2.4{ }^{\circ} \mathrm{C}$ and $21.8^{\circ} \mathrm{C}$, respectively), and elevation of studied area varies between 907 and 1012 m (GDM, 2020).

\section{Study design and sample collection}

This cross-sectional study was carried out during the months of February 2018 and March 2019 on 43 cattle herds. The sample size was determined based on expected prevalence of $50 \%$ with $95 \%$ confidence level (CI) and a precision of $5 \%$. In this study, a two-stage cluster sampling was used. The initial sample size $(n=384)$ was increased to 557 animals (6-54 months) with the design effect based on parameters used in sampling: number of herds $=43$, number of sampling animals in each herd $=2$, and design effect $=1.45$ and intraclass correlation coefficient $($ ICC $)=0.28$ which are values mentioned for BRSV (Segura et al. 2013). A random sampling programme (Win Episcope 2.0) was used to determine the number of animals by random sampling in each selected herd (Sergeant 2017). To avoid misinterpretation of results due to presence of maternal immunity among young cattle, cattle $>6$ months of age were sampled.

For BRSV detection, nasal swabs were collected from 21 cattle (aged between 1 and 9 months) suspected to have BRSV infection with clinical signs including cough, ocular and nasal discharge. Samples originated from four beef herds in the Uşak Province and seven dairy herds in the Afyonkarahisar Province. On these herds, there were no vaccination records against BRSV. The medical history of sampled herds was obtained from questionnaire survey.

\section{Serological assays}

Blood samples were collected using a sterile vacuum tube without an anticoagulant from the jugular vein and transferred to the laboratory on frozen ice. Sera were separated by centrifugation $\left(3000 \mathrm{rpm}\right.$ for $15 \mathrm{~min}$ at $20^{\circ} \mathrm{C}$ ) and stored in a freezer (at $-20^{\circ} \mathrm{C}$ ) until analysis. A commercial indirectELISA kit (BIO K 061/5, BioX, Rochefort, Belgium) was used for the detection of BRSV anti-F specific antibodies in the sera samples. The reported specificity and sensitivity of the kit were $87 \%$ and $93 \%$, respectively. The optical density was measured using a spectrophotometer (BioTek Instruments Inc., Winooski, USA) at $450 \mathrm{~nm}$. ELISA results were evaluated according to the manufacturer's instructions. 


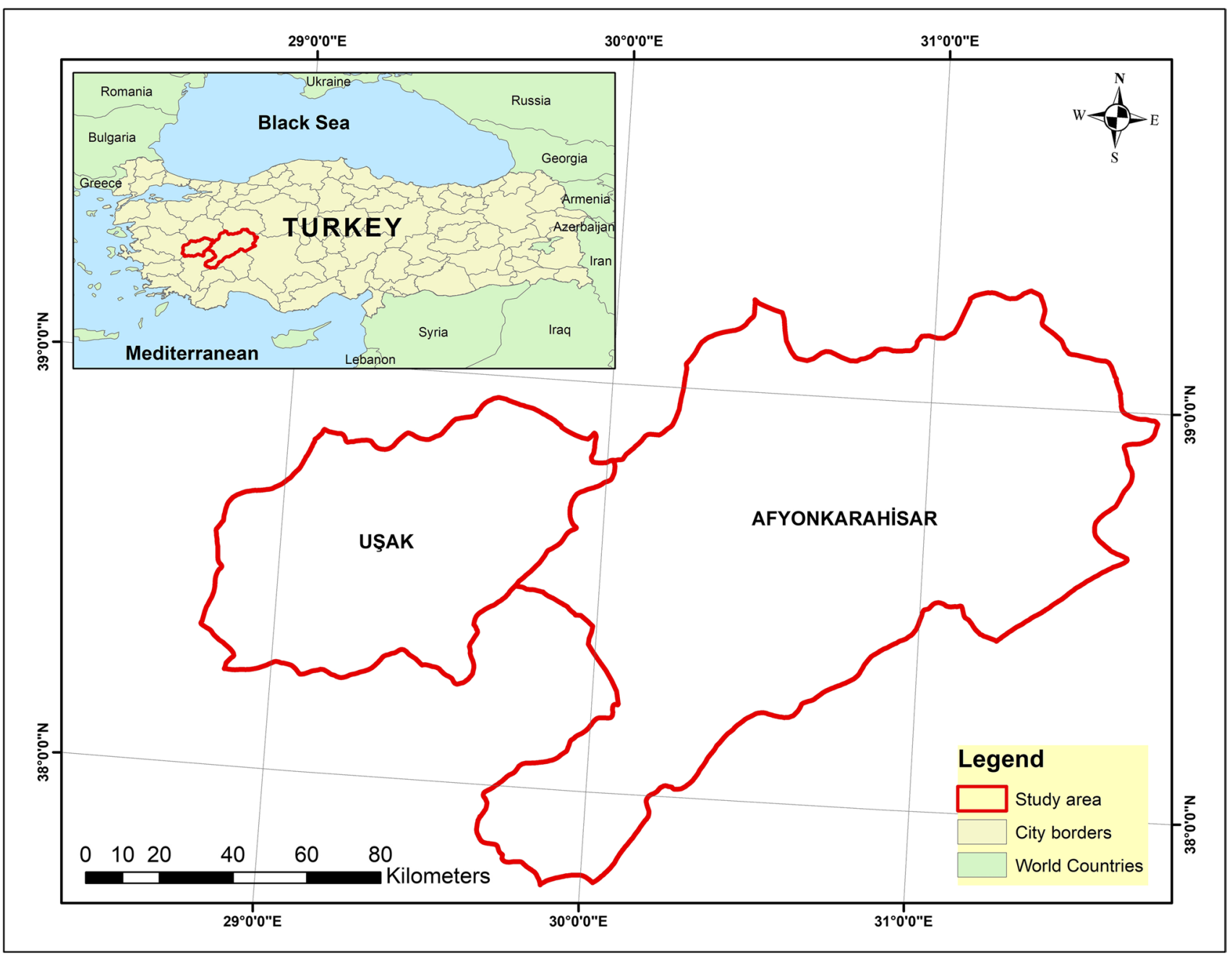

Fig. 1 Location of sampled provinces in Turkey

\section{Nucleic acid extraction and screening BRDC associated viruses}

A commercial extraction kit (Cador Pathogen Mini Kit, Qiagen, Hilden, Germany) was used for the extraction of total nucleic acids from the nasal swabs. Total nucleic acids were tested by RT-PCR methods for detection of bovine parainfluenza-3 (BPIV-3), bovine viral diarrhoea virus (BVDV), and BRSV. The protocols described by Valarcher et al. (2000), Zhu et al. (2011), and Vilcek et al. (2001) were used for detection of BRSV, BPIV-3, and BVDV, respectively. Furthermore, samples were also tested by a PCR method described by Vilcek et al. (1994) that detects BoHV-1.

\section{Genetic analysis of the $\mathbf{G}$ gene}

The amplicons were purified with a commercial kit (QIAquick Gel Extraction Kit, Qiagen, Hilden, Germany) and sequenced in both orientations. ABI $3130 \times 1$ DNA
Analyser (Applied Biosystems, USA) was used for the collection of sequence data. The sequence reads were analysed and aligned using BioEdit software version 7.0.5.3. Phylogenetic tree with neighbour-joining method and bootstrap 1000 replicates was constructed for $\mathrm{G}$ gene segments of BRSV using the MEGA $\times$ software version 10.2.4 (Kumar et al. 2018). The GenBank accession numbers of BRSV field strains from this study are MW881233 and MW881234.

BRSV has been divided into seven subgroups based on the $\mathrm{G}$ gene sequence variability, designated as subgroup I-VII (Bertolotti et al. 2018). Subgroup I of BRSV strains is isolated in Switzerland and the UK; subgroup II includes strains isolated in Belgium, Denmark, France, Japan, and Sweden; subgroup III includes strains isolated in the USA; subgroup IV contains European and US strains; subgroups $\mathrm{V}$ and VI include Belgian and French isolates; and subgroup VII includes Italian strains (Valarcher et al. 2000; Bidokhti et al. 2012; Sarmiento-Silva et al. 2012; Bertolotti et al. 2018). The $G$ gene sequences of BRSV strains representing 
seven different subgroups were obtained from the GenBank and were used in the phylogenetic analysis.

\section{Risk factors}

To assess risk factors associated with BRSV seropositivity, a questionnaire was administered to herd owners during the blood sampling. The questionnaire included; type of herd (dairy or beef), size of herd ( $\leq 20$ or $>20$ cattle), age of the animal (06-12 months or $>12$ months), history of past respiratory disease (yes or no), cattle origin (purchased or born on herd), and season (winter or summer). In addition, all 43 herds had similar climate classification, altitude, and breeds, so data on these variables were not included in the analyses.

\section{Data analysis}

Descriptive statistics were used to analyse the obtained data from the sampled herds. A herd was defined as positive if at least one of the samples was seropositive within herd. The mean seropositivity within positive herds was used to calculate the within-herd seropositivity. The true seropositivity of BRSV in sampled herds was calculated from the apparent seropositivity, specificity, and sensitivity of the ELISA kit and with 95\% CI (Rogan and Gladen method), using EpiTools (Sergeant 2017).

A dummy variable was created for a season variable with more than two categories. Generalised estimating equation (GEE) model was used to determine risk factors at individual level, and the herd was included as random effect. The choice of correlation structure (either independent or unstructured) within the GEE model was based on the quasiinformation criteria (QIC). The association between possible risk factors and the BRSV seropositivity was evaluated using a univariate analysis. Those significant factors $(p \leq 0.20)$ were analysed by multivariate GEE model. An assessment of the model's goodness of fit was performed with a Hosmer-Lemeshow test (Dohoo et al. 2009). Odds ratios (OR) and standard errors were assessed using the method of GEE with an "exchangeable" correlation matrix among observations within each herd. Statistical analyses were performed using SPSS package version 21 (SPSS Inc., Chicago, IL, USA). $P$ value $<0.05$ was considered statistically significant.

\section{Results}

\section{Seropositivity and associated risk factors of BRSV}

Out of the 557 sera collected from 43 herds, 333 sera were positive for BRSV. The apparent individual-based seropositivity of BRSV was 59.78\% (95\% CI: 55.66-63.78). After adjustment for Ab-ELISA test kit sensitivity and specificity, the overall true seropositivity was $58.48 \%$ (95\% CI: 53.32-63.47). All sampled herds had at least one seropositive cattle, and intra-herd seropositivity found in this study ranged from 21.43 to $91.67 \%$.

The prevalence of BRSV antibodies was higher during the winter $(60.80 \%)$ than in summer $(58.10 \%)$. Fever (above $40{ }^{\circ} \mathrm{C}$ ), coughing, loss of appetite, and nasal discharge were the most common clinical signs reported in the infected herds. The results of the study showed that herds with a past history of respiratory disease had significantly higher seropositivity of BRSV (RR: 1.80, 95\% CI: 1.51-2.14) (Table 1).

According to univariate analysis, six factors were found to be associated with BRSV seropositivity. Potential risk factors associated with BRSV seropositivity are presented in Table 1. Seropositivity was higher in cattle $>12$ months of age compared with cattle aged between 6 and 12 months (RR: 1.43), and BRSV seropositivity was higher in herds
Table 1 Risk factors associated with BRSV infection in cattle

\begin{tabular}{llllllll}
\hline Variable & Category & Positive & Negative & $P(\%)$ & $R R$ & $95 \%(\mathrm{CI})$ & $p$-value \\
\hline Age & $>12$ months & 258 & 135 & 65.65 & & & \\
\multirow{3}{*}{ Herd size } & $06-12$ months & 75 & 89 & 45.73 & 1.43 & $1.19-1.72$ & 0.0001 \\
& $>20$ & 275 & 75 & 78.57 & & & \\
Herd type & $\leq 20$ & 58 & 149 & 28.02 & 2.8 & $2.23-3.51$ & $<0.0001$ \\
& Dairy & 262 & 69 & 79.15 & & & \\
Season & Beef & 71 & 155 & 31.42 & 2.51 & $2.06-3.07$ & $<0.0001$ \\
& Winter & 211 & 136 & 60.80 & & & \\
A past history & Summer & 122 & 88 & 58.10 & 1.04 & $0.90-1.20$ & 0.5 \\
of respiratory & Yes & 245 & 93 & 72.49 & & & \\
disease & No & 88 & 131 & 40.18 & 1.80 & $1.51-2.14$ & $<0.0001$ \\
Cattle origin & Purchased & 132 & 79 & 62.56 & & & \\
& Born in herd & 201 & 145 & 58.09 & 1.07 & $0.93-1.23$ & 0.29 \\
\hline
\end{tabular}

$C I$ confidence interval, $P$ seroprevalance, $R R$ relative risk 
with $>20$ cattle (RR: 2.8 ) and dairy herds (RR: 2.51). The GEE model determined that age ( $>12$ month $)(\mathrm{OR}=2.36$; CI \%95: $1.43-3.89)$, herd size $(\mathrm{OR}=10.32 ; 95 \% \mathrm{CI}$ : 6.32-16.82), herd type $(\mathrm{OR}=8.97,95 \%$ CI: 5.51-14.58), and history of past respiratory disease $(\mathrm{OR}=4.06,95 \% \mathrm{CI}$ : 2.50-6.61) are risk factors for BRSV infection (Table 2).

\section{Detection and genetic characterization of the BRSV}

BRSV-specific RNA was detected in 2 of the 21 nasal swabs, and these two RT-PCR-positive samples were sequenced and phylogenetic analysis was done. The sequence analysis of the G gene showed that the two isolates in the present study had $99.3 \%$ homology, whereas homology with previously characterised BRSV isolates ranged between 78.8 and $96 \%$, the lowest with Italian isolate (IT16813) and highest with previous Turkish isolate (ESK/25/TR). A 98.6\% amino acid sequence similarity was observed among the two isolates from this study. BRSV field isolates TR/AFYONKARAHISAR/2019 displayed 5 nucleotide substitutions in the G gene compared to TR/AFYONKARAHISAR/2018 isolate (A404G,
G424A, and C459T). Two of the 5 nucleotide substitutions were non-synonymous substitutions. The mutations K135R (from a hydrophilic to a hydrophilic residue) and A142T (from a hydrophobic to a hydrophilic residue) were found in the TR/AFYONKARAHISAR/2019 isolate. The two BRSV field isolates isolated in present study displayed 3 amino acid substitutions (P89S, D115G, and S165L) in the $\mathrm{G}$ protein chains compared to other main reference BRSV isolates from Belgium, Croatia, Denmark, Italy, France, Switzerland, Sweden, Netherlands, Turkey, the USA, and the UK (Fig. 2). These amino acid substitutions have not been reported.

The phylogenetic tree based on $\mathrm{G}$ gene sequences showed that field isolates in the present study belonged to subgroup III, but they were located on separate branch from previously characterised Turkish subgroup III isolates (Fig. 3).

\section{Other viral agents of BRDC}

BPIV-3 and BVDV RNA and BoHV-1 DNA were not detected in the investigated nasal samples.
Table 2 Results of the multivariate GEE model of risk factors associated to BRSV seropositivity

\begin{tabular}{|c|c|c|c|c|c|c|}
\hline Variable & Category & $B$ & $S E$ & $O R$ & $95 \% \mathrm{CI}$ & $p$-value \\
\hline \multirow[t]{2}{*}{ Age } & $>12$ months* & & & & & \\
\hline & $6-12$ months & 0.86 & 0.25 & 2.36 & $1.43-3.89$ & 0.001 \\
\hline \multirow[t]{2}{*}{ Herd size } & $>20 *$ & & & & & \\
\hline & $\leq 20$ & 2.34 & 0.24 & 10.32 & $6.32-16.82$ & $<0.001$ \\
\hline \multirow[t]{2}{*}{ Herd type } & Dairy* & & & & & \\
\hline & Beef & 2.19 & 0.24 & 8.97 & $5.51-14.58$ & $<0.001$ \\
\hline \multirow{2}{*}{$\begin{array}{l}\text { A past history of res- } \\
\text { piratory disease }\end{array}$} & Yes* & & & & & \\
\hline & No & 1.41 & 0.24 & 4.06 & $2.50-6.61$ & $<0.001$ \\
\hline
\end{tabular}

Estimates and SE were assessed using generalized estimating equation (GEE) with an "exchangeable" correlation matrix among observations within each herd (intercept $=-3.292$; model QIC: 472.072)

$B$ regression coefficient, $S E$ standard error, $O R$ odds ratio

${ }^{*}$ Reference category

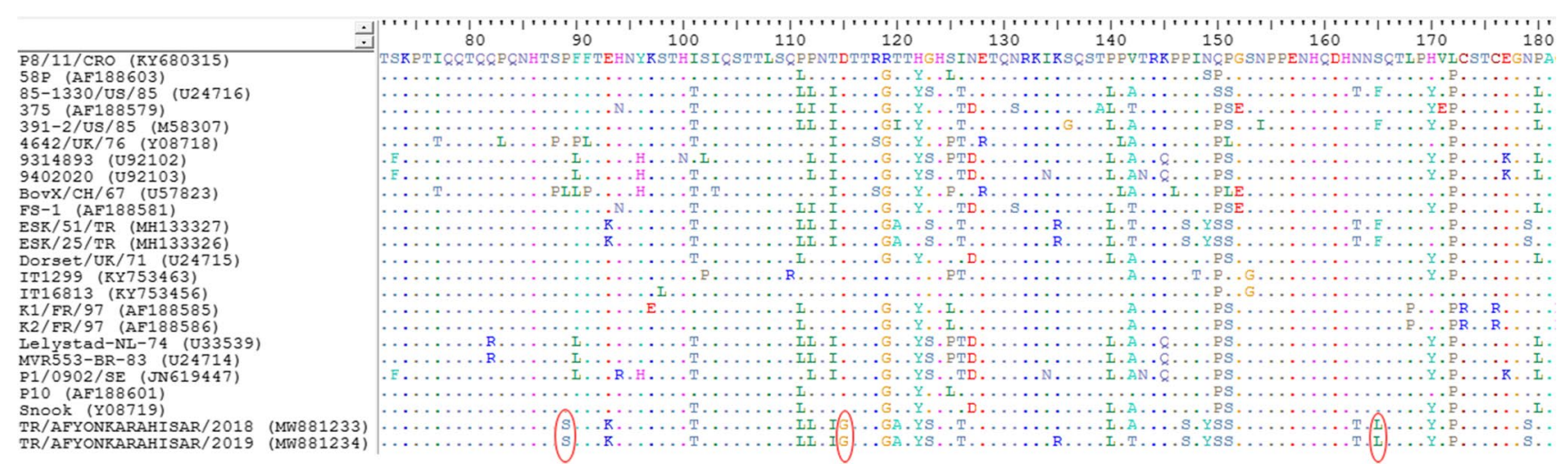

Fig. 2 Amino acid replacements on G protein in BRSV field isolates from this study when compared with main reference BRSV isolates 
Fig. 3 Phylogenetic tree constructed based on the 410-nt sequences of attachment glycoprotein gene. The sequences from this study clustered in a separate branch from the previously characterised Turkish isolates in subgroup III, and they are marked with round black spot

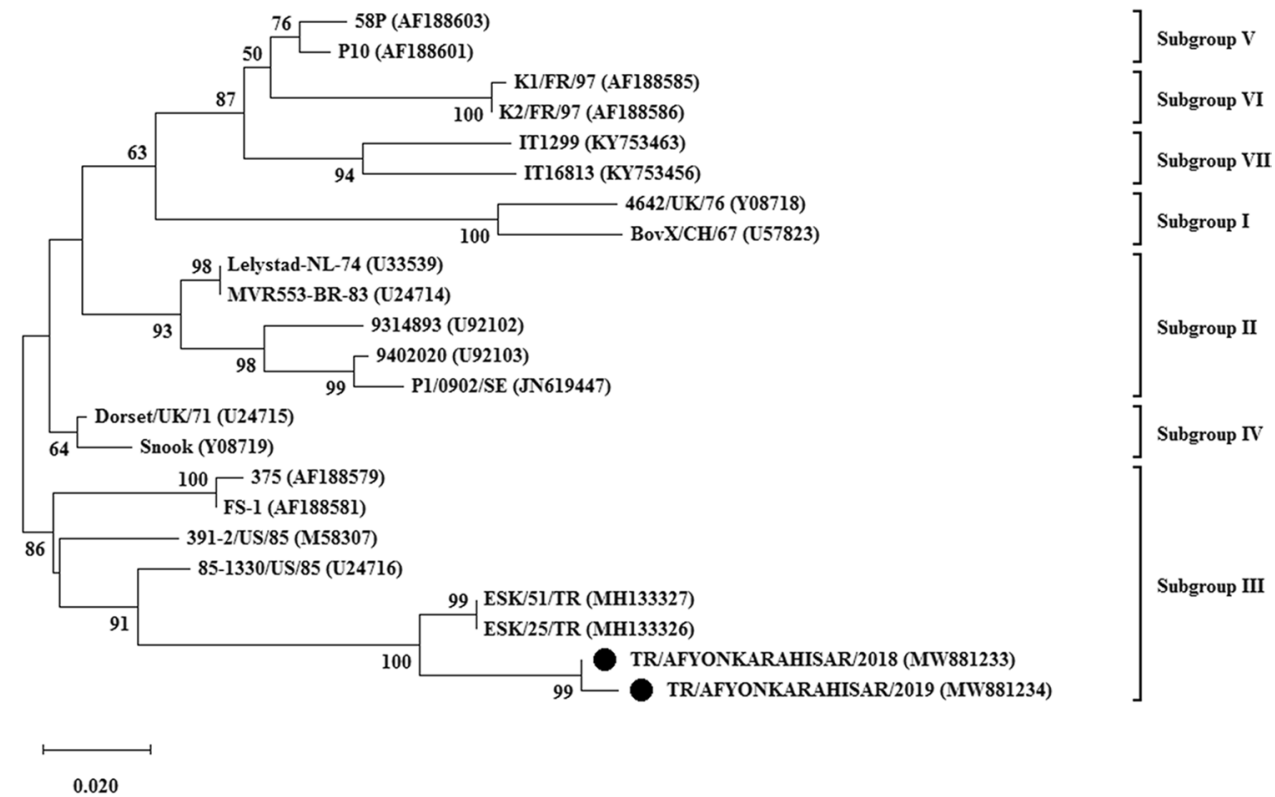

\section{Discussion}

Determining risk factors and seropositivity studies at the country level are important to implementing appropriate and effective prevention measures against viral infections. A control and eradication programme against BRSV has not yet been implemented in Turkey. There is scant knowledge about the prevalence and genetic diversity of BRSV in cattle herds in Turkey. The aims of this study were therefore to provide data about the risk factors associated with BRSV seropositivity and genetic diversity of BRSV in cattle and to contribute to the development of control measures against BRSV infection in Turkey. To our knowledge, this is the first epidemiological study that evaluated possible risk factors for BRSV infection in cattle in Turkey.

The individual seropositivity $(59.78 \%)$ obtained in this study was in accordance with previous studies that reported seropositivity of BRSV in cattle ranged between $46.06 \%$ and 73\% in Turkey (Yavru et al. 2005; Yeşilbağ and Güngör, 2008; Kadiroğlu et al. 2020). The highest seropositivity (73\%) was found in Marmara region of Turkey. In Marmara region, most of the farms are large-scale farms ( $>50$ cattle). Therefore, the highest seropositivity in Marmara region may be result of close contact between infected and uninfected cattle in larger herds. Serologic BRSV prevalence rate in the Aegean region was previously reported $68.38 \%$ (Karaotcu and Yildirim 2019). However, in this study, BRSV seropositivity in the Aegean region was $59.78 \%$. The differences between our and previous result may be related to the sample size, the age of animals, and management conditions.

The lower seropositivity found in this study compared with previous studies that reported seropositivity of BRSV in cattle were 67\% in Finland (Härtel et al. 2004), 79.5\% in Brazil (Hoppe et al. 2018), and 80.48\% in Ecuador (Saa et al. 2012). However, higher seropositivity found in this study compared with previous studies that reported seropositivity of BRSV in cattle was $30 \%$ in Sweden (Hägglund et al. 2006), 30.2\% in Argentina (Odeón et al. 2001), $31.2 \%$ in Norway (Gulliksen et al. 2009), 50.8\% in Mexico (Figueroa-Chávez et al. 2012), and 51.1\% in central region of Iran (Shirvani et al. 2011). Possible explanations for the differences in seropositivity of BRSV in different countries are the number of sampled animals, the time of sampling, the detection method, housing conditions, and insufficient information about the disease and management conditions.

There was a significant relationship between the age of animals and BRSV infection. The GEE model showed that age was an important risk factor for BRSV infection $(\mathrm{OR}=2.36$; CI \%95: 1.43-3.89, $p=0.001)$ (Table 2). The seropositivity of BRSV in adult animals ( $>12$ months) was higher than that expected in adult animals (>12 months), which reached $65.65 \%$ of samples. This result is in agreement with the previous studies (Figueroa-Chávez et al. 2012; Hoppe et al. 2018). The seropositivity (45.73\%) in young animals (06-12 months) was lower than in adult animals, and it could be even lower due to maternal antibody and immunological status. Higher seropositivity of BRSV infection in adult cattle can be explained by the reinfection with BRSV throughout their life.

The analysis of risk factors for the prevalence of BRSV antibodies showed that type of herd was risk factor. It was found that BRSV is widespread among dairy herds compared with beef herds $(\mathrm{OR}=8.97,95 \% \mathrm{CI}: 5.51-14.58$, $p<0.001$ (Table 2). This finding is in agreement with previous studies conducted by Norström et al. (2000) and Saa et al. (2012). Beef herds in Turkey have a better 
biosecurity level than dairy herds. High seropositivity of BRSV infection in dairy herds can be explained by the intensive animal farming, increased herd traffic by herd employees for milk delivery or artificial insemination, and dairy farmers prefer high milk yield so stress induced by practices to produce high milk yields could suppress the immune system (Norström et al. 2000; Dahl et al. 2020).

At herd level, size of herd has been identified as risk factor increasing seropositivity of BRSV. The BRSV seropositivity was significantly higher in large herds $(>20$ cattle) than in small herds ( $\leq 20$ cattle $)(\mathrm{OR}=10.32 ; 95 \% \mathrm{CI}$ : $6.32-16.82, p<0.001$; Table 2). This finding is in agreement with previous studies (Van Donkersgoed et al. 1993; Norström et al. 2000; Hoppe et al. 2018). The number of animals susceptible to infection in large herds is higher than in small herds, which may contribute maintenance of infection, and increasing transmission rate of the infection within the herd (Norström et al. 2000). Biosecurity measures can be applied to prevent the introduction of viral infections into herds and to reduce the prevalence of infection in endemic regions.

Furthermore, the seropositivity rate of BRSV was higher during the winter than in summer, which is in agreement with previous reports that reported incidence rate of BRSV is much higher in colder seasons (Hägglund et al. 2007; Luzzago et al. 2010). The possible explanations for the higher seropositivity in winter could be due to inclement weather, close confinement of animals, and poorly managed barns combined with poor ventilation. In this study, herds with a past history of respiratory disease had significantly higher seropositivity of BRSV (OR = 4.06, 95\% CI: 2.50-6.61 $p<0.001$; Table 2), which is in agreement with previous report that reported incidence rate of BRSV is much higher in herds with history of respiratory disease (Hägglund et al. 2006). It can be said that history of respiratory disease in early life might be associated with increased prevalence of BRSV infection. However, a study conducted in southern Brazil did not identify historical of respiratory disease as a risk factor for BRSV infection. The possible explanations for the difference could be due to the level of herd owners' knowledge, the conditions of care and feeding, the immune status of the host, the age of animals, and the sample size. The movement of infected animals is a risk factor for disease spread (Kobayashi et al. 2014; Şevik et al. 2015). Purchased animals and cattle introduced from other herds are thought to be responsible for transmission of BRSV infection, which was confirmed in a previous study that reported BRSV infection occurred frequently following the introduction of purchased animals (Elvander 1996). However, in this study, GEE model showed that presence of purchased cattle was not a risk factor for BRSV infection. The differences between our and previous results may be related to the differences between herds in the number of animals purchased and management conditions. Further researches are required to determine the effect of purchased cattle on BRSV infection.

In our study, BRSV RNA was detected in two of 21 (9.5\%) nasal samples. However, other viruses, most frequently associated with BRD include BoHV1, BVDV, and BPIV-3 were not detected. In this study, samples were not tested for the presence of bovine adenovirus, bovine coronavirus, and bacterial agents that associated with BRD such as Mycoplasma bovis and Pasteurella multocida (Härtel et al. 2004). It is, therefore, possible that negative samples were infected with viral and bacterial agents which were not tested in this study. Furthermore, BRSV mainly causes lower respiratory tract infection and BRSV replication in the upper respiratory tract only occurs in an early stage of infection (Larsen 2000; Viuff et al. 2002). It has also been reported that BRSV RNA can be detected in nasal swab samples for up to four weeks (Klem et al. 2019). This could explain why viral RNA was detected in only 2 of 21 nasal samples. Bronchoalveolar lavage and lung tissues are more suitable samples for the detection of BRSV in later stages of the disease (Larsen 2000; Viuff et al. 2002).

It has been reported that there is a significant interaction between geographic regions and genetic subgroups of BRSVs (Yaegashi et al. 2005). Turkey is a bridge between Europe and the Middle East due to its geographic location. The G gene phylogenetic tree showed that BRSVs from Turkey were grouped in subgroup III with isolates from the USA and Italy (Fig. 3). This result is in agreement with earlier studies that reported BRSV subgroup III is in circulation in Turkey (Hacioglu et al., 2019; Timurkan et al. 2019; Yazici et al. 2020). However, field isolates in this study were genetically separated from the most of the other European strains. Turkey imports live animals from the USA and some of the European countries. The importation of live animals from the USA and European countries to Turkey suggests that source of infection appears to be animal trade. Further researches are required to identify the source of infection.

The $G$ protein has a function in the virion attachment to host cell surfaces. Furthermore, G protein is one of the major protective antigens of BRSV, and specific antibodies inhibit the entry of virus into target cells (Taylor et al. 1997). It has been reported that mutations in $\mathrm{G}$ protein, particularly in the immunodominant region between amino acids (aa) 174-188, may cause imperfect vaccine protection (Valarcher and Taylor 2007). The mutation N179S was found in our BRSV isolates (Fig. 2). Therefore, to provide effective protection vaccines should include local BRSV isolates. Further studies are needed to determine the genetic and antigenic relationships between field isolates circulating in Turkey and vaccine virus.

The four cysteine (Cys) residues (173C, 176C, 182C, 186C), called as cysteine noose, are highly conserved in respiratory syncytial viruses (Akerlind-Stopner et al. 1990). 
Based on sequence analysis, all Cys residues were conserved in our field isolates (Fig. 2). However, translated sequences showed multiple amino acid substitutions in the $G$ protein (Fig. 2). G protein consists of three regions: cytoplasmic (located between 1 and 37 aa), transmembrane (38-65 aa), and extracellular (66-257 aa) (Langedijk et al. 1996). In this study, amino acid substitutions have been detected in the extracellular region of the $\mathrm{G}$ protein. This region is responsible for binding the virus to the host cells (Lerch et al. 1990). Furthermore, mutations in $\mathrm{G}$ protein provide an opportunity for viral escape from naturally induced immunity (AkerlindStopner et al. 1990; Taylor et al. 1997). Therefore, it can be speculated that detected amino substitutions might be associated with facilitation of viral attachment to host cell surfaces and escape from previously established immunity.

In conclusion, the results of the study demonstrate that the BRSV infection is common in cattle herds in the inner Aegean region of Turkey. To improve knowledge of the epidemiology of BRSV, infection could help to develop effective prevention and control strategies. The age, herd size, herd types, and history of past respiratory disease are risk factors for BRSV infection in the surveyed region. These factors should be taken into account when developing control strategies for BRSV infection. Furthermore, biosecurity measures should be implemented to reduce the incidence of BRSV in herds. Genetic analyses of the detected BRSVs showed the circulation of BRSV subgroup III in Turkey and indicated that BRSV is still evolving. The evolutionary changes are especially important in developing more effective BRSV vaccines.

Acknowledgements The authors thank Alparslan AYAZ and his veterinarian colleagues for their help during the sample collection.

Author contribution Ömer Barış İnce (incebaris@gmail.com) 0000-0001-8302-9607.

Contribution: investigation, laboratory analyses, statistical analyses, writing — original draft.

Murat Şevik (dr_muratank@ @otmail.com) 0000-0002-9604-3341.

Contribution: methodology, laboratory analyses, writing, review and editing, interpretation and discussion of results.

Emrah Gökay Özgür (emrahgokayozgur@gmail.com) 0000-0002-3966-4184.

Contribution: statistical analyses, review and editing.

Ahmet Sait (saitvet@ gmail.com) 0000 0001-7658-8793.

Contribution: methodology, laboratory analyses, review and editing.

Data availability The data that support the findings of this study are available from the corresponding author upon reasonable request.

Code availability (software application or custom code). Not applicable.

\section{Declarations}

Ethics approval Not applicable. In this study, no experimental procedures were performed on animals. The blood collection process was conducted in the context of routine veterinary medicine, with the consent of the animal owners to blood sampling and in line with international recommendations.

Consent to participate Not applicable.

Consent for publication Not applicable.

Conflict of interest The authors declare no competing interests.

\section{References}

Akerlind-Stopner, B., Utter, G., Mufson, M.A., Orvell, C., Lerner, R.A., Norrby, E., 1990. A subgroup-specific antigenic site in the $\mathrm{G}$ protein of respiratory syncytial virus forms a disulfide-bonded loop, Journal of Virology, 64, 5143-5148, https://doi.org/10.1128/ JVI.64.10.5143-5148.1990.

Bertolotti, L., Giammarioli, M., Rosati, S., 2018. Genetic characterization of bovine respiratory syncytial virus strains isolated in Italy: evidence for the circulation of new divergent clades, Journal of Veterinary Diagnostic Investigation, 30, 300-304, https://doi. org/10.1177/1040638717746202.

Bidokhti, M.R., Tråvén, M., Ohlson, A., Zarnegar, B., Baule, C., Belák, S., Alenius, S., Liu, L., 2012. Phylogenetic analysis of bovine respiratory syncytial viruses from recent outbreaks in feedlot and dairy cattle herds, Archives of Virology, 157, 601-607, https://doi. org/10.1007/s00705-011-1209-3.

Brodersen, B.W., 2010. Bovine respiratory syncytial virus, Veterinary Clinics of North America Food Animal Practice, 26, 323-333.

Dahl, G.E., Tao, S., Laporta, J., 2020. Heat stress impacts immune status in cows across the life cycle, Frontiers in Veterinary Science, 7, 116, https://doi.org/10.3389/fvets.2020.00116.

Dohoo, I.R., Martin, S.W., Stryhn, H., 2009. Veterinary epidemiologic research. 2nd ed. VER Inc., Charlottetown, PEI, Canada.

Elvander, M., 1996. Severe respiratory disease in dairy cows caused by infection with bovine respiratory syncytial virus, Veterinary Record, 138,101-105, https://doi.org/10.1136/vr.138.5.101.

Ferella, A., Aguirreburualde, M.S.P., Margineda, C., Aznar, N., Sammarruco, A., Santos, M.J.D., Mozgovoj, M., 2018. Bovine respiratory syncytial virus seroprevalence and risk factors in feedlot cattle from Córdoba and Santa Fe, Argentina, Revista Argentina de Microbiología, 50, 275-279, https://doi.org/10.1016/j. ram.2017.07.004.

Figueroa-Chávez, D., Segura-Correa, J.C., García-Márquez, L.J., Pescador-Rubio, A., Valdivia-Flores, A.G., 2012. Detection on antibodies and risk factors for infection with bovine respiratory syncytial virus and parainfluenza virus 3 in dual purpose farms in Colima, Mexico, Tropical Animal Health and Production, 44, 1417-1421, https://doi.org/10.1007/s11250-012-0081-9.

General Directorate of Meteorology (GDM), 2020. Climate classification, https://www.mgm.gov.tr/iklim/iklim-siniflandirmalari. aspx?m, Accessed 05 May 2020

Gulliksen, S.M., Jor, E., Lie, K.I., Løken, T., Akerstedt, J. and Østerås, O., 2009. Respiratory infections in Norwegian dairy calves, Journal of Dairy Science, 92, 5139-5146, https://doi.org/10.3168/ jds.2009-2224.

Hacıoğlu, I.K., Çoşkun, N., Yelken, S.D., Sevinç, S., Alkan, F., 2019. Phylogenetic analysis of bovine respiratory syncytial virus from calves with respiratory disorders, Kafkas Universitesi Veteriner Fakültesi Dergisi, 25, 251-256, https://doi.org/10.9775/ kvfd.2018.20819.

Hägglund, S., Hjort, M., Graham, D.A., Ohagen, P., Törnquist, M., Alenius, S., 2007. A six-year study on respiratory viral infections 
in a bull testing facility, The Veterinary Journal, 173, 585-593, https://doi.org/10.1016/j.tvj1.2006.02.010.

Hägglund, S., Svenson, C., Emanuelson, U., Valarcher, J. and Alenius, S., 2006. Dynamics of virus infection involved in the bovine respiratory disease complex in Swedish dairy herds, Veterinary Journal, 172, 320-328, https://doi.org/10.1016/j.tvj1.2005.04.029.

Härtel, H., Nikunen, S., Neuvonen, E., Tanskanen, R., Kivela, S., Aho, P., Soveri, T., Saloniemi, H., 2004. Viral and bacterial pathogens in bovine respiratory disease in Finland, Acta Veterinaria Scandinavica, 45, 193-200, https://doi.org/10.1186/1751-0147-45-193.

Hoppe, I.B.A.L., Medeiros, A.S.R., Arns, C.W. Samara, S.I., 2018. Bovine respiratory syncytial virus seroprevalence and risk factors in non-vaccinated dairy cattle herds in Brazil. BMC Veterinary Research, 14, 208, https://doi.org/10.1186/s12917-018-1535-8.

International Committee on Taxonomy of Viruses (ICTV). 2019. https://talk.ictvonline.org/ictv-reports/ictv_online_report/negative-sense-rna-viruses/w/pneumoviridae/738/genus-orthopneumovirus Accessed 2 April 2021

Kadiroğlu, B., Alpay, G., Yesilbag, K., 2020. Seroprevalance of respiratory viruses and pestivirus screening in ruminant species in Diyarbakır Region, Turkey, Journal of Research in Veterinary Medicine, 39, 26-33.

Karaotcu, A., Yildirim Y. 2019. Serological Investigation of Bovine Respiratory Syncytial Virus Infection in Cattle in the Denizli and Burdur Districh, Journal of Health Sciences Institute, 7, 114-123, https://doi.org/10.24998/maeusabed.646933.

Klem, T.B., Sjurseth, S.K., Sviland, S., Gjerset, B., Myrmel, M., Stokstad, M., 2019. Bovine respiratory syncytial virus in experimentally exposed and rechallenged calves; viral shedding related to clinical signs and the potential for transmission, BMC veterinary research, 15, 156, https://doi.org/https://doi.org/10.1186/ s12917-019-1911-z.

Kobayashi, S., Hidano, A., Tsutsui, T., Yamamoto, T., Hayama, Y., Nishida, T., Muroga, N., Konishi, M., Kameyama, K., Murakami, K., 2014. Analysis of risk factors associated with bovine leukemia virus seropositivity within dairy and beef breeding farms in Japan: a nationwide survey, Research in Veterinary Science, 96, 47-53.

Krešić, N., Bedeković, T., Brnić, D., Šimić, I., Lojkić, I., Turk, N., 2018. Genetic analysis of bovine respiratory syncytial virus in Croatia. Comparative Immunology, Microbiology and Infectious Diseases, 58, 52-57.

Kumar, S., Stecher, G., Li, M., Knyaz, C., Tamura, K., 2018. MEGA X: Molecular evolutionary genetics analysis across computing platforms, Molecular Biology and Evolution, 35, 1547-1549.

Langedijk, J.P., Schaaper, W.M., Meloen, R.H., van Oirschot, J.T., 1996. Proposed three-dimensional model for the attachment protein $\mathrm{G}$ of respiratory syncytial virus, Journal of General Virology, $77,1249-1257$.

Larsen, L.E., 2000. Bovine respiratory syncytial virus (BRSV): a review, Acta Veterinaria Scandinavica, 41, 1-24. https://doi. org/https://doi.org/10.1186/BF03549652.

Lerch, R.A., Anderson, K., Wertz, G.W., 1990. Nucleotide sequence analysis and expression from recombinant vectors demonstrate that the attachment protein $G$ of bovine respiratory syncytial virus is distinct from that of human respiratory syncytial virus, Journal of Virology, 64, 5559-5569, https://doi.org/10.1128/ JVI.64.11.5559-5569.1990.

Luzzago, C., Bronzo, V., Salvetti, S. Frigerio M, Nicola F., 2010. Bovine respiratory syncytial virus seroprevalence and risk factors in endemic dairy cattle herds, Veterinary Research Communications, 34, 19-24, https://doi.org/https://doi.org/10.1007/ s11259-009-9327-z.

Norström, M., Skjerve, E., Jarp J., 2000. Risk factors for epidemic respiratory disease in Norwegian cattle herds, Preventive Veterinary Medicine, 44, 87-96, https://doi.org/https://doi.org/10.1016/ s0167-5877(99)00113-0.
Odeón, A., Spath, E., Paloma, E., Leunda, M., Sainz, F., Pérez, S., Kaiser, G., Draghi, M., Cetra, B., Cano, A., 2001. Seroprevalencia de la diarrea viral bovina, herpes virus bovino y virus syncytial respiratorio en Argentina, Revista de Medicina Veterinaria, 82, 216-220.

Saa, L.R., Perea, A., Jara, D.V. Arenas AJ, Garcia-Bocanegra I, Borge C, Carbonero A., 2012. Prevalence of and risk factors for bovine respiratory syncytial virus (BRSV) infection in non-vaccinated dairy and dual-purpose cattle herds in Ecuador, Tropical Animal Health and Production, 44, 1423-1427, https://doi.org/10.1007/ s11250-012-0082-8.

Sarmiento-Silva, R.E., Nakamura-Lopez, Y., Vaughan, G., 2012. Epidemiology, molecular epidemiology and evolution of bovine respiratory syncytial virus, Viruses, 4, 3452-3467, https://doi. org/10.3390/v4123452.

Sacco, R.E., McGill, J.L., Pillatzki, A.E., Palmer M.V., Ackermann M.R., 2014. Respiratory syncytial virus infection in cattle, Veterinary Pathology, 51, 427-436, https://doi.org/https://doi.org/10. 1177/0300985813501341.

Şevik, M., Avc1, O., Ince, O.B., 2015. An 8-year longitudinal seroepidemiological study of bovine leukaemia virus (BLV) infection in dairy cattle in Turkey and analysis of risk factors associated with BLV seropositivity, Tropical Animal Health and Production, 47, 715-720, https://doi.org/https://doi.org/10.1007/ s11250-015-0783-x.

Segura, C., Figueroa, C.D., García, M.L., Pescador, R.A., 2013. Parainfluenza-3 and bovine respiratory syncytial virus: intraherd correlation adjusted for sensitivity and specificity, Revista MVZ Córdoba, 18, 3807-3811.

Sergeant ESG., 2017. Epitools epidemiological calculators: Ausvet Pty Ltd, http://www.epitools.ausvet.com.au, Accessed 01 May 2018

Shirvani, E., Lotfi, M., Kamalzadeh, M., Noaman, V., Bahriari, M., Morovati, B., Hatami, A., 2011. Seroepidemiological study of bovine respiratory viruses (BRSV, BoHV-1, PI-3V, BVDV, and BAV-3) in dairy cattle in central región of Iran (Esfahan province). Tropical Animal Health and Production, 44, 191-195, https://doi. org/10.1007/s11250-011-9908-z.

Taylor, G., Thomas, L.H., Furze, J.M., Cook, R.S., Wyld, S.G., Lerch, R., Hardy, R., Wertz, G.W., 1997. Recombinant vaccinia viruses expressing the $\mathrm{F}, \mathrm{G}$ or $\mathrm{N}$, but not the M2, protein of bovine respiratory syncytial virus (BRSV) induce resistance to BRSV challenge in the calf and protect against the development of pneumonic lesions, Journal of General Virology, 78, 3195-3206, https://doi.org/10.1099/0022-1317-78-12-3195.

Timurkan, M.O., Aydin, H., Sait, A., 2019. Identification and molecular characterisation of bovine parainfluenza virus- 3 and bovine respiratory syncytial virus - first report from Turkey, Journal of Veterinary Research, 63, 167-173, https://doi.org/https://doi.org/ 10.2478/jvetres-2019-0022.

Turkish Statistical Institue (TUIK), 2019. Animal data.https://turkstatweb.tuik.gov.tr/ Accessed 05 May 2019

Valarcher, J.F., and Taylor, G., 2007. Bovine respiratory syncytial virus infection, Veterinary Research, 38, 153-180, https://doi. org/https://doi.org/10.1051/vetres:2006053.

Valarcher, J.F., Schelcher, F., Bourhy, H., 2000. Evolution of bovine respiratory syncytial virus, Journal of Virology, 74, 10714-10728, https://doi.org/https://doi.org/10.1128/jvi.74.22.10714-10728. 2000.

Van der Poel, W.H., Brand, A., Kramps, J.A., van Oirschot, J.T., 1994. Respiratory syncytial virus infections in human beings and in cattle, The Journal of Infectious Diseases, 29, 215-228, https://doi. org/https://doi.org/10.1016/s0163-4453(94)90866-4.

Van Donkersgoed, J., Ribble C.S., Boyer L.G., Townsend H.G.G., 1993. Epidemiological study of enzootic pneumonia in dairy calves in Saskatchewan, Canadian Journal of Veterinary Research, $57,247-254$. 
Vilcek, S., Nettleton, P.F., Herring, J.A., Herring, A.J., 1994. Rapid detection of bovine herpesvirus 1 (BHV 1) using the polymerase chain reaction, Veterinary Microbiology, 42, 53-64, https://doi. org/https://doi.org/10.1016/0378-1135(94)90077-9.

Vilcek, S., Paton, D.J., Durkovic, B., Strojny, L., Ibata, G., Moussa, A., Loitsch, A., Rossmanith, W., Vega, S., Scicluna, M.T., Paifi, V., 2001. Bovine viral diarrhoea virus genotype 1 can be separated into at least eleven genetic groups, Archives of Virology, 146, 99-115, https://doi.org/https://doi.org/10.1007/s007050170194.

Viuff, B., Tjornehoj, K., Larsen, L.E., Rontved, C.M., Uttenthal, A., Ronsholt, L., Alexandersen, S., 2002. Replication and clearance of respiratory syncytial virus: Replication and clearance of respiratory syncytial virus, The American Journal of Pathology, 161, 2195-2207, https://doi.org/https://doi.org/10.1016/S00029440(10)64496-3.

Yaegashi, G., Seimiya, Y.M., Seki, Y., Tsunemitsu, H., 2005. Genetic and antigenic analyses of bovine respiratory syncytial virus detected in Japan, Journal of Veterinary Medical Science, 67, 145-150, https://doi.org/https://doi.org/10.1292/jvms.67.145.

Yavru, S., Şimsek, A., Yapkiç, O., Kale, M., 2005. Serological evaluation of viral infections in bovine respiratory tract, Acta Veterinaria (Beograd), 55, 219-226.
Yazici, Z., Ozan, E., Tamer, C., Muftuoglu, B., Barry, G., Kurucay, H.N., Elhag, A.E., Cagirgan, A.A., Gumusova, S., Albayrak, H., 2020. Circulation of indigenous bovine respiratory syncytial virus strains in Turkish cattle: the first isolation and molecular characterization, Animals (Basel), 10,1700. https://doi.org/https://doi. org/10.3390/ani10091700.

Yeşilbağ, K., Güngör, B., 2008. Seroprevalence of bovine respiratory viruses in North-Western Turkey, Tropical Animal Health Production 40, 55-60, https://doi.org/https://doi.org/10.1007/ s11250-007-9053-X.

Zhu, Y.M., Shi H.F., Gao Y.R., Xin J.Q., Liu N.H., Xiang W.H., Ren X.G., Feng J.K., Zhao L.P., Xue F., 2011. Isolation and genetic characterization of bovine parainfluenza virus type 3 from cattle in China, Veterinary Microbiology, 149, 446-451, https://doi. org/https://doi.org/10.1016/j.vetmic.2010.11.011.

Publisher's Note Springer Nature remains neutral with regard to jurisdictional claims in published maps and institutional affiliations. 